\title{
MEDIA EDUKATIF TEKA-TEKI SILANG DALAM PEMBELAJARAN SOSIOLOGI DI KELAS X IPS SMA N 13 PADANG
}

Arian Puspa Rinri, Buchari Nurdin, Yenni Melia

Program Studi Pendidikan Sosiologi STKIP PGRI Sumatera Barat

Arianpusparinri@gmail.com

\begin{abstract}
His research is based on the lack of innovation of teachers in preparing instructional media in preparing lesson plans. This study aims to 1) describe the learning design using the crossword puzzle media 2) describe the learning scenario using the cross puzzle 3) compile the form of learning evaluation tools using the crossword puzzle media. The method used in this research is a qualitative approach method, in the form of descriptive, using data collection techniques in this study are documents, observation and interviews and literature study. data analysis through the stages of data collection, data presentation, and drawing conclusions. The results of the research conducted at SMA Negeri 13 Padang, researchers 1) Planning learning with educational media Cross Puzzle the results formulate learning objectives. The results of the research design used the cognitive domain at the level of understanding and analysis. Students understand the concepts and facts in the material and a crossword puzzle box will be made which is filled in by students down and horizontally for each material explained. 2) Creating a learning scenario arranges the time allocation from the initial activity, and the core activity has the nuances of Cross Puzzle students are able to explain and analyze each indicator, for that it will be tested using Cross Puzzle filling in the empty boxes horizontally and descending and closing the learning 3 ) Determine the form of evaluation tool in the form of essay questions that students will do at the end of each less.
\end{abstract}

\section{Keywords: Planning, Educational Media Cross Puzzle, Sociology Learning.}

\section{PENDAHULUAN}

Pembelajaran merupakan suatu sistem, yang terdiri dari berbagai komponen yang saling berhubungan satu dengan yang lain. Komponen tersebut meliputi: tujuan, materi, metode, serta alat evaluasi. Keempat komponenter sebut harus diperhatikan oleh guru dalam memilih dan menentukan media, metode, strategi dan pendekatan apa yang akan digunakan dalam proses kegiatan pembelajaran. Dengan demikian Pembelajaran hakikatnya merupakan proses interaksi antara guru dan siswa, baik interaksi secara langsung seperti kegiatan tatap muka maupun secara tidak langsung, yaitu dengan menggunakan berbagai bentuk media pembelajaran. Didasari oleh adanya 
perbedaan interaksi tersebut, maka kegiatan pembelajaran dapat dilakukan dengan menggunakan berbagai pola pembelajaran.

Terwujudnya tujuan pembelajaran yang telah ditetapkan sebelumnya maka guru harus memiliki cara atau strategi yang baik agar suasana kelas selama pembelajaran dalam kondisi aman dan menyenangkan (Wasgito, 2014:37).

Salah satu yang terpenting dalam pembelajaran adalah pemilihan media yang akan digunakan oleh guru, di dalam kelas guru harus bisa merancang media sendiri untuk menarik perhatian siswa dalam belajar. Jadi media pembelajaran adalah alat yang digunakan untuk membantu guru menyampaikan isi materi atau informasi yang akan disampaikan ke siswa, kegunaan media ini tujuannya agar memudahkan komunikasi guru dan siswa tersampaikan dengan baik. (Wati, 2016:3).

Media menurut batasannya adalah perangkat lunak yang berisikan pesan suatu informasi pendidikan yang lazimnya disajikan dengan menggunakan peralatan., media dikelompokan dalam dua jenis, pertama media (by utilazation) yaitu media yang di perdagangkan di pasaran, kedua media rancangan yaitu media yang dipersiapkan secara khusus untuk maksud atau tujuan pembelajaran tertentu ( media by design ). Santi 2017 dalam (Sadiman, 2017:83).

Media yang akan digunakan untuk proses pembelajaran itu juga memerlukan perencanaan yang baik. Perancanaan merupakan menyiapkan materi apa yang akan digunakan, pemilihan metode, serta penilaian agar tujuan yang sebelumnya tercapai (Majid, 2011:16).

Selain itu media pembelajaran yang ditampilkan dapat memotivasi siswa untuk lebih rajin belajar. Media pembelajaran juga dapat memberikan rangsangan dalam kegiatan belajar siswa, bahwa media pembelajaran dapat memberikan pengaruh psikologis terhadap siswa. Penggunaan media pembelajaran dapat membantuk ke akktifan siswa dalam proses pembelajaran dan kemudahan bagi guru dalam menyampaikan pesan dan isi materi (Wati, 2016: 8-9). 
Berdasarkan observasi yang sebelumnya hanya lebih melihat peneliti lakukan di SMA N 13 Padang menemukan beberapa masalah dalam penggunaan media pembelajaran. Media yang monoton dalam kegiatan pembelajaran tidak menantang peserta didik untuk belajar. Supaya terwujudnya pembelajaran yang efektif maka tugas guru adalah harus mempunyai strategi yang menarik dan kreatif. Salah satunya yaitu media edukatif teka-teki silang, media tekateki silang dapat mengasah otak berfikir peserta didik, media ini bagus digunakan kerena media ini menantang, menyenangkan untuk peserta didik.

Penelitian yang dilakukan sebelumnya Lakoro, 2020 melakukan penelitian berkaitan dengan judul "media edukatif teka-teki silang terhadap hasil belajar geografi di SMA N 1 Marisa" bahwa hasil peelitiannya mengatakan adanya unsur positif di dalam penerapan media tersebut dan media ini meningkatkan hasil belajar pada siswa. Yang membedakan dengan penelitian peneliti bahwa peneliti hanya merancang dan membuat skenario pemelajaran dengan desain teka-teki silang berbeda dengan penelitian

kepada hasil belajar siswa.

Dengan demikian dilakukan penelitian dengan membuat perencanaan dengan media teka-teki silang, menyusun skenario pembelajaran dengan teka-teki silang serta alat evaluasi yang dipakai dalam pembelajaran dengan media teka-teki silang.

\section{METODE PENELITIAN}

Tipe penelitian yang digunakan dalam penelitian ini adalah menggunakan penelitian deskripstif. Menurut (Arikunto, 2010:9) mengungkapkan bahwa penelitian deskriptif adalah memaparkan atau menggambarkan sesuatu hal, misalnya keadaan, kondisi, situasi peristiwa, kegiatan, dan lain-lain. Penelitian ini mendeskripsikan media edukatif teka-teki silang dalam pembelajaran Sosiologi di kelas $\mathrm{X}$ IPS SMA N 13 Padang.

Informan dalam penelitian kualitatif adalah orang yang akan memberikan informasi baik tentang dirinya maupun tentang kejadian pada peneliti (Afrizal, 2014:65). Informan dalam penelitian ini guru 
Sosiologi yang berjumlah 2 orang ibu Dra. Revida dan Bpk Iswandi Arista S.Pd yang mengajar dan membuat rancangan pembelajaran mata pelajaran Sosiologi.

Jenis data yang dipakai yaitu data primer dilakukan dalam bentuk survei atau observasi dan sekunder dalam bentuk dokumen yang terdahulu. Tekhnik pengumpulan data pertama yaitu pertama studi dokumen merupakan catatan peristiwa yang sudah belalu, bentuk dokumen yang peneliti kumpulkan yaitu RPP (Rencana Pelaksanaan Pembelajaran) mata pelajaran Sosiologi. Kedua yaitu Observasi Sutrisno Hadi, 1986 dalam (Sugiyono, 2013:145) mengemukan bahwa observasi merupakan suatu proses yang kompleks, suatu proses yang tersusun dari berbagai proses biologis dan psikologis. Observasi yang peneliti lakukan waktu melaksanakan PPLK di SMA N 13 Padang cara guru menngajar dan memakai media selama proses kegiatan pembelajaran di dalam kelas, dan jenis media yang sering digunakan oleh guru sosiologi seperti menuliskan peta konsep hanya di papan tulis, memakai power point. Ketiga yaitu wawancara, menurut (Sugiyono, 2013:231) wawancara digunakan sebagai teknik pengumpulan data apabila peneliti ingin melakukan studi pendahuluan untuk menemukan permasalahan yang harus diteliti. Peneliti melakukan wawancara dengan 2 orang guru sosiologi tentang membuat rancangan pembelajaran dan skenario pembelajaran dilanjutkan dengan memakai alat evaluasi.

Unit analisis dalam penelitian ini adalah individu diantaranya yaitu guru Sosiologi yang mengajar di SMA N 13 Padang dengan menggunakan analisis data Miles dan Huberman dengan mengumpulkan data, reduksi data, penyajian data, penerikan kesimpulan. Lokasi dalam penelitian ini yaitu di SMA N 13 Padang.

Penelitian ini menggunakan Teori Kognitif yang dikemukakan oleh Piaget dengan menggunakan pendekatan kualitatif . Pendekatan kualitatif menurut Maleong (2013:11) menceritakan fenomena yang terjadi dengan berbagai metode dengan cara menggambarkan dengan kata-kata. 


\section{HASIL DAN PEMBAHASAN}

Berdasarkan hasil penelitian yang dirancang terkait dengan media edukatif teka-teki silang dalam pembelajaran Sosiologi di kelas X IPS SMA N 13 Padang sebagai berikut:

1. Rancangan Pembelajaran dengan Menggunakan Media Edukatif Teka-Teki Silang di Kelas X IPS SMA N 13 Padang

Peneliti membuat rancangan pembelajaran dengan menggunakan media edukatif teka-teki silang dalam pembelajaran Sosiologi. Langkah pertama yang dilakukan dalam membuat rancangan adalah memnentukan silabus dan buku sumber. Mengisi identitas sekolah kelas/semester mata pelajaran dan menentukan alokasi waktu. setelah itu menentukan Kompetensi Dasar yang akan digunakan dan dijabarkan ke dalam beberapa indikator dengan menggunakan Kata Kerja Operasional. Untuk di kelas X IPS di SMA N 13 Padang guru Sosiologi menggunakan tiga Kompetensi Dasar untuk satu semester ini.

Selanjutnya membuat langkahlangkah pembelajaran dari membuka sampai menutup pembelajaran, sebelum peneliti melakukan penelitian yang membedakan dengan guru sosiologi terkait langkah-langkah pembelajaran yaitu dalam kegiatan inti pembelajaran guru sosiologi menggunakan kegiatan mengamati, menanya, mencoba, menalar, mengkomunikasikan, simpulan Sedangkan hasil penelitian yang telah dilakukan bahwa pada kegiatan inti pembelajaran menggunakan stimulation, problem steatment, data processing, verifikation, generalisasi.

KD 3.1 Untuk KD ini akan menjabarkan 8 indikator. Pertemuan pertama akan dijelaskan 4 indikator. Untuk pertemuan pertama ini siswa paham mengenai konsep dan penjelasan dari keempat indikator agar tujuan pembelajaran tercapai, maka peneliti akan merancang dan membuat media teka-teki silang dengan cara mendatar dan menurun dan di isi oleh siswa sampai ke indikator ke delapan untuk tercapainya tujuan pembelajaran.

KD 3.2 Mengenali dan mengidentifikasi realitas individu kelompok dan hubungan Sosial di masyarakat. Indikator untuk KD 3.2 ini menjabarkan 8 indikator . pertemuan pertama ada 3 indikator 
yang akan dijelaskan. Pada pertemuan pertama ini siswa harus paham tentang konsep dan fakta ketiga indikator ini, untuk itu guru akan melakukan tes kepada siswa dengan mengisi kotak kosong tts secara mendatar dan menurun sampai pertemuan ke 3 untuk 8 indikator pada KD 3.2 .

KD 3.3 Indikator ini akan menjakabarkan 7 indikator untuk 4 kali pertemuan-pertemuan pertama ada 3 indikator yang akan dijelaskan. Pertemuan pertama ini siswa harus paham mengenai konsep dan penjelasan dari ketiga indikator tersebut dan melihat fakta dan realitas dari penjelasan materi tersebut untuk itu siswa akan mengisi kotak kosong teka-teki silang dengan soal yang telah disediakan secara mendatar dan menurun sampai ketujuh indikator pada KD 3.3 ini untuk 4 kali pertemuan.

2. Skenario Pembelajaran dengan Menggunakan Media Edukatif Teka-Teki Silang

Skenario pembelajaran merupakan urutan cerita yang dirancang dan disusun oleh guru dari pembuka, kegiatan pembelajaran sampai kepenutup dan disusun sesuai rencana. Skenario pembelajaran teka-teki silang untuk semester ganjil di kelas $\mathrm{X}$ ips ditentukan 3 Kompetensi Dasar yang dipakai.

Skenario pembelajaran langkah awal dilakukan selama 25 menit pada kegiatan awal ini guru akan mengkondisikan kelas, dan setelah kegiatan awal dilakukan guru akan melakukan kegiatan inti pembelajaran dilakukan selama 105 ada 5 tahap yang dilaksanakan oleh guru dan siswa tahap pertama yaitu memberikan Stimulation (pemberian rangsangan) guru akan menampilkan sebuah gambar untuk diamati oleh siswa sesuai materi Interaksi sosial, Problem Steatment ( Identifikasi Masalah) siswa setelah mengamati gambar tersebut akan memahami maksud dari gambar terkait materi interaksi sosial, Data Procesing (Pengolahan Data) guru akan mencari data dan informasi terkait materi interaksi sosial dengan menggunakan sumber-sumber yang ada menggunakan buku maupun internetan yang bisa digunakan, Verification (Pemeriksaan Data) guru dan siswa akan menyelesaikan informasi yang sedang di cari tersebut untuk menemukan 
jawabannya, Generalization (Penarikan

Kesimpulan) barulah guru dan siswa akan menyimpulkan hasil temuannya. Setiap materi per Indikator yang akan dijelaskan oleh guru, siswa akan mengisi kotak kosong teka-teki silang secara mendatar dan menurun dengan soal yang telah disusun oleh guru. Setelah tujuan pembelajaran telah dilaksanakan guru akan melakukan tes pemahaman siswa dengan teka-teki silang.

Setelah melakukan kegiatan inti dilaksanakan maka dilakukan evaluasi oleh guru untuk memberikan soal esay dan dikerjakan oleh siswa dilaksanakan selama 10 menit. Setalah tes dilakukan guru akan melakukan refleksi di dalam kelas dan mengingatkan kembali kepada siswa untuk mengulang pembelajaran di rumah dan pembelajaran ditutup.

3. Alat atau Tekhnik Evaluasi dalam Pembelajaran Sosiologi dengan Menggunakan Media Edukatif Teka-Teki Silang.

Apabila pembelajaran telah dilaksanakan oleh guru sesuai dengan skenario di atas, maka guru harus menentukan tekhnik atau alat evaluasi dalam bentuk: a. Test

Test yang dilakukan dalam bentuk Post Test yang dilakukan setelah akhir pembelajaran. Sedangkan jenis soal yang digunakan yaitu dalam bentuk soal esay disusun oleh peneliti dan akan dikerjakan oleh masing-masing siswa dan setelah materi pokok telah selesai dilaksanakan nantinya guru kan melakukan test kembali dengan bentuk LKPD (Lembar Kerja Peserta Didik). Ada 3 Kompetensi dasar yang peneiti rancang, untuk setiap pertemuan ada 3 indikator yang dijelaskan dan setelah kegiatan pembelajaran telah dilaksanakan siswa akan dilakukan tes dalam bentuk soal esay yang telah dibuat.

b. Menilai

Setelah melakukan kegiatan pembelajaran guru akan menilai setiap proses yang diikuti oleh siswa kriteria keberhasilan penilaian mencangkup yaitu Kognitif, Afektif dan Psikomotor. Dalam aspek Kognitif (Pengetahuan) siswa akan dinilai dari test yang dilakukan tadi keberhasilan siswa dalam menjawab soal yang diberikan setiap pertemuan skor yang didapatkan sesuai pada 
tingkatan yang diberikan jika soalnya menjelaskan maka skor yang didapatkan 10 point jika soal berupa analisis point yang diberikan cukup tinggi 25 point, itu semua tergantung pada kerumitan dan kemudahan soal. Yang kedua cara penilaian afektif (sikap) ini dilakukan pada hasil observasi selama proses pembelajaran berlangsung, baik sikap, tingkah laku, sopan santu itu semua akan dinilai. Pada penilaian ketiga psikomotor (keterampilan) keterampilan perlu juga dinilai oleh guru keterampilan individu maupun kelompok.

\section{Pembahasan}

Teori yang digunakan dalam penlitian ini adalah teori kognitif yang dikemukakan oleh Piaget. Piaget mengatakan model belajar kognitif bahwa tingkah laku seseorang ditentukan oleh persepsi yang ditangkapnya. Belajar juga merupakan persepsi pehamannya yang selalu dapat terlihat sebagai tingkah laku yang nampak (Budiningsih, 2005:34).

Teori Piaget membagi tahap perkembangan kognitif menjadi empat tahap perkembangan pertama perkembangan Sensomonitor dilakukan pada umur 0-2 tahun pertumubuhan yang masih dibimbing, kedua perkembangan Preoperasional ini lakukan lakukan pada anak berumur 2-8 tahun, ketiga perkembangan Operasional Konkret dilakukan pada anak berumur 8-11 tahun, keempat perkembangan Operasional Formal pada anak berumur 11-18 tahun.

Melalui rancangan dalam membuat media teka-teki silang ini teori Piaget lebih melihat kepada proses yang diikuti oleh siswa melalui beberapa perkembangan bukan melihat kepada hasil belajar. Siswa akan mengeluarkan ide-ide atau potensi yang ada pada dirinya melalui pembelajaran yang menyenangkan seperti bermain games teka-teki silang ini tujuannya untuk membangkitkan interaksi siswa dalam mengikuti proses pembelajaran. Artinya guru harus bisa membuat rancangan media yang menarik dan kreatif untuk kegiatan atau proses belajar tersebut supaya meningkatkan minat belajar yang diikuti oleh siswa di dalam kelas serta merancang dan membuat skenario dengan nuansa teka-teki silang untuk meningkatkan motivasi belajar siswa dengan cara bermain 
games, agar suasana dikelas menjadi monoton akan tetapi menyenangkan dan seru.

\section{KESIMPULAN}

Rancangan menggunakan media Edukatif Teka-Teki Silang dalam penelitian ini mentukan Kompetensi Dasar lalu menjabarkan dan merumuskan kedalam Indikator. Penelitian ini menggunakan $3 \mathrm{KD}$. Indikator KD 3.1 ini menjabarkan dan merumuskan delapan indikator. Setiap indicator penelitian akan menggunakan kata kerja operasional yaitu pemahaman (C2) menganalisis (C4) setiap indicator penelitian akan membuat rancangan media Teka-Teki Silang dalam bentuk soal menurun dan mendatar yang akan diisi oleh masingmasing siswa seperti 1 . Mendeskripsikan sejarah lahirnya Sosiologi dengan indikator ini siswa dapat menceritakan kembali sejarah lahirnya Sosiologi dengan itu siswa akan mengisi kotak Teka-Teki Silang dengan cara menurun dan mendatar. Sampai ke Kompetensi Dasar 3.2 dan Kompetensi Dasar 3.3

Membuat skenario pembelajaran dirancang dari awal masuk, kegiatan inti sampai penutup, urutan cerita yang akan diterapkan di dalam kelas, mengatur semua jadwal, kegiatan apa saja yang nantinya yang akan dikerjakan. Setiap indikator yang akan dijelaskan kepada siswa dan melakukan tes untuk pemahaman siswa terhadap materi. Akan dilakukan tes dengan cara membuatTeka-Teki Silang dengan lajur mendatar dan lajur menurun.

Tekhnik evaluasi dilakukan setiap selesai proses pembelajaran dilakukan tujuannya untuk mengukur sejauh mana kemampuan siswa terhadap materi yang telah dipelajari dan mengetahui pemahaman siswa, berhasil atau tidaknya guru dalam mengajar. Bentuk alat yang nantinya diuku rdengan memberikan test baik dalam bentuk soal dan setelah memberikan test baru melakukan penilaian terhadap siswa.

\section{DAFTAR PUSTAKA}

Afrizal. (2014). Metode Penelitian Kualitatif. PT RajaGrafindo Persada.

Arikunto, S. (2010). Prosedure Penelitian Suatu Pendekatan Praktik. Rineka Cipta.

Majid, A. (2011). Perencanaan 
Pembelajaran Mengembangkan Kompotensi Guru. PT Remaja Rosdakarya.

Sadiman, A. (2017). Media Pendidikan. Rajawali.

Sugiyono. (2013). Metode Penelitian Kuantitaif Kualitatif dan $R \& D$. Alfabeta CV.

Wasgito, M. A. (2014). Pengembangan Media Permainan Edukatif TekaTeki Silang (TTS) dalam Proses Pembelajaran Siswa Kelas VII SMP Negeri 2 Kalianget. Pendidikan Seni Rupa, 2.

Wati, E. R. (2016). Ragam Media Pembelajaran. Kata Pena. 